\title{
HUBUNGAN KADAR ZINK SERUM DENGAN DERAJAT NEUROPATI DIABETIK
}

\author{
THE ASSOCIATION BETWEEN SERUM ZINC LEVELS AND SEVERITY OF \\ DIABETIC NEUROPATHY \\ Udi Panata, * Dodik Tugasworo, * Amin Husni*
}

\section{ABSTRACT}

Introduction: Diabetic neuropathy (DN) is one of the complications in diabetes mellitus (DM) that occurs frequently. This might be caused by deficiencies of trace elements, such as zinc, related to the complications. Zinc controls hyperglycemic factor and oxidative stress caused by hyperglycemia, which causes DN.

Aim: To analyze the association between serum zinc levels and severity of DN in patients with type 2 DM.

Methods: An observational analytical study with cross-sectional approach was conducted. Sixty subjects diagnosed with type 2 DM in the Neurology Clinic of Dr. Kariadi General Hospital, Semarang and HM Ashari General Hospital, Pemalang were scored using Toronto Clinical Scoring System (TCSS) to measure severity of DN. Characteristic data were analyzed descriptively. Categorical analysis were analyzed using Mann-Whitney method. The variables were also analyzed using Mann-Whitney test and unpaired t-test between Semarang and Pemalang Hospitals. Furthermore, all variables were tested for multivariate analysis using linear regression.

Results: There were 60 subjects with a majority of females (63.3\%) who suffer from DN (90\%) and of $52.35 \pm 4.02$ years old in age with duration of disease of $9.37 \pm 3.44$ years. On average, the serum zinc levels were found normal, while average triglyceride and HbAlc levels were increased. It was observed that there were correlations among DN severity, serum zinc levels, duration of DM disease and serum triglyceride levels. In multivariate data analysis, the most significant relationship was found between triglyceride levels and duration of DM disease.

Discussion: Hyperglycemia causes glucose accumulation in nerve tissues. In a long period of time, high blood glucose levels will damage the blood vessels walls that are directly related to nerves. Furthermore, in elderly patients, the amount of blood flow to peripheral nerves decreases. High triglyceride levels becomes a predictive factor that severely decreases myelin nerve fibers density. Whereas, zinc can prevent the decrease in motor nerve conduction speed.

Keywords: DN, serum zinc levels, type 2 DM

\section{ABSTRAK}

Pendahuluan: Neuropati diabetik (ND) adalah salah satu komplikasi diabetes melitus (DM) yang lebih sering terjadi. Hal ini dapat disebabkan oleh defisiensi trace element akibat komplikasi diabetes, antara lain zink. Elemen ini mengendalikan faktor hiperglikemik dan stres oksidatif yang disebabkan oleh hiperglikemia, hingga menyebabkan ND.

Tujuan: Menganalisis hubungan kadar zink serum dengan derajat ND pada pasien DM tipe 2, dan faktor-faktor lain yang memengaruhinya.

Metode: Penelitian analitik observasional secara potong lintang terhadap pasien DM tipe 2 yang berobat di Poliklinik Penyakit Saraf RSUP Dr. Kariadi, Semarang dan RSUD HM Ashari, Pemalang. Subjek dilakukan pengukuran derajat ND menggunakan Toronto Clinical Scoring System (TCSS). Data karakteristik dianalisis secara deskriptif. Analisis kategorikal menggunakan metode Mann-Whitney, pengujian antar variabel juga dengan Mann-Whitney dan uji t tidak berpasangan, serta uji multivariat menggunakan regresi linear.

Hasil: Didapatkan 60 subjek yang mayoritas perempuan $(63,3 \%)$ dan menderita ND $(90 \%)$, serta rerata usia

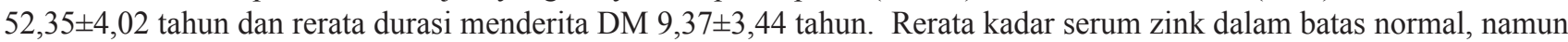
rerata kadar trigliserida dan HbA1c meningkat. Didapatkan hubungan antara ND dengan kadar serum zink, durasi penyakit DM, dan kadar trigliserida serum. Dalam analisis data multivariat, hubungan tertinggi ditemukan antara kadar trigliserida dan durasi penyakit DM.

Diskusi: Hiperglikemia menyebabkan akumulasi glukosa pada jaringan saraf. Jangka waktu yang cukup lama, kadar glukosa dalam darah akan merusak dinding pembuluh darah kapiler yang berhubungan langsung ke saraf, ditambah lagi pada usia lanjut terjadi penurunan aliran darah pada pembuluh darah yang menuju saraf tepi. Kadar trigliserida yang tinggi menjadi faktor prediktif penurunan secara dramatis pada masa jenis atau kepadatan serabut saraf mielin. Zink dapat mencegah penurunan kecepatan konduksi saraf motorik.

Kata kunci: DM tipe 2, kadar zink serum, neuropati diabetik

*Bagian Neurologi FK UNDIP/RSUP Dr. Kariadi, Semarang. Korespondensi: dokter.udi@gmail.com. 


\section{PENDAHULUAN}

Diabetes melitus (DM) merupakan salah satu ancaman kesehatan manusia. Penyakit ini tidak menular, tetapi jumlah penderitanya akan terus meningkat. ${ }^{1}$ Indonesia menduduki negara peringkat ke-4 terbesar dengan pertumbuhan penderita DM sebesar $152 \%$ yaitu 8.426 .000 orang pada tahun 2000 meningkat mencapai 21.257 .000 orang pada tahun 2030. ${ }^{2}$ Prevalensi penyakit DM tipe 2 di Jawa Tengah tahun 2016 mencapai 119.400 kasus. Dua daerah dengan jumlah kasus DM tipe 2 tertinggi pada tahun 2016 yaitu di Semarang (10.377 kasus) dan Pemalang (10.264 kasus). ${ }^{3}$

Komplikasi DM digolongkan menjadi komplikasi akut dan komplikasi kronik. Komplikasi kronik dapat dibagi menjadi 2, yaitu komplikasi makrovaskular, seperti penyakit jantung koroner, trombosis serebral, dan gangren, serta komplikasi mikrovaskular, berupa retinopati, neuropati, dan nefropati diabetik. ${ }^{4}$

Neuropati diabetik (ND) merupakan penyebab neuropati perifer tersering, yang ditandai dengan kerusakan difus pada serabut saraf perifer. Hal ini terutama berupa polineuropati diabetik sensorimotor yang menyebabkan penurunan kualitas hidup dan morbiditas yang signifikan, serta peningkatan biaya perawatan kesehatan. ${ }^{5-6}$ Data Badan Penyelenggara Jaminan Sosial (BPJS) tahun 2016 di Poli Penyakit Dalam RSUD Dr. HM Ashari, Pemalang menyebutkan penderita diabetes melitus yang mengalami komplikasi kronis neuropati tergolong cukup tinggi, yang mayoritas (72\%) disebabkan oleh DM tipe $2 .^{7}$

Defisiensi trace element tertentu mempunyai hubungan dengan terjadinya komplikasi diabetes, antara lain zink. Elemen ini berperan dalam pengendalian faktor hiperglikemia dan mengendalikan stres oksidatif karena hiperglikemia, sebagai penyebab neuropati diabetik. Hiperglikemia menyebabkan degenerasi saraf melalui peningkatan stres oksidatif dikarenakan peningkatan sel-sel radikal bebas berlebihan. ${ }^{5-6}$

Metabolisme dan gangguan oksidatif ini menyebabkan perubahan sangat cepat pada sel glia. Adapun stres oksidatif pada sistem saraf tepi menyebabkan defek neurovaskular hasil hipoksia endoneural dan serangkaian disfungsi saraf, sehingga terjadi neuropati diabetik. Stres oksidatif ini berhubungan dengan perkembangan apoptosis pada neuron dan penyokong sel glia yang menyebabkan mekanisme perusakan sistem saraf pada DM. Trace element seperti zink dijumpai lebih rendah pada penderita diabetes dibandingkan dengan individu sehat. $^{5-6}$

Pemeriksaan baku emas dalam menegakkan ND adalah dengan pemeriksaan elektroneuromiografi (ENMG), namun tidak selalu tersedia di setiap rumah sakit. Oleh karena itu, digunakan Toronto Clinical Scoring System (TCSS) sebagai salah satu sistem skoring sederhana untuk membantu menegakkan diagnosis ND. Validasi antara TCSS dengan pemeriksaan ENMG menunjukkan sensitivitas dan spesifisitas TCSS yang cukup tinggi (sensitivitas $79,4 \%$, spesifisitas 59,4\%). ${ }^{8}$ Lama menderita DM tipe 2 memengaruhi timbulnya gejala klinis neuropati, yaitu penderita neuropati paling banyak terdapat pada rentang 1-10 tahun menderita diabetes melitus tipe 2. Untuk setiap penambahan durasi 1 tahun, maka gejala klinis neuropati akan muncul 1,11 kali pada penderita neuropati dibandingkan dengan yang bukan penderita neuropati. ${ }^{9}$

Oleh karena tingginya angka prevalensi penderita DM di Semarang akan meningkatkan risiko terjadinya ND, sehingga perlu mencari hubungan kadar zink serum dengan derajat neuropati diabetik pada pasien dengan DM tipe 2.

\section{TUJUAN}

Mengetahui hubungan antara kadar zink serum dengan derajat ND pada pasien DM tipe 2.

\section{METODE}

Penelitian analitik observasional dengan metode potong lintang terhadap pasien DM tipe 2 dewasa yang berobat di Instalasi Rawat Jalan SMF Ilmu Penyakit Saraf RSUP Dr. Kariadi, Semarang dan RSUD HM Ashari, Pemalang. Sampel diambil secara randomized sampling pada bulan Desember 2016 sampai dengan selesai. 
Kriteria inklusi adalah pasien DM tipe 2 berusia $>25$ tahun dan bersedia mengikuti penelitian. Kriteria eksklusi antara lain subjek yang mendapat terapi zink, sedang hamil, memiliki riwayat gangguan fungsi ginjal, gizi buruk, riwayat merokok, dan yang menggunakan obat diuretik. Variabel bebas dalam penelitian ini adalah kadar serum zink; variabel tergantung adalah neuropati perifer (skrining berdasarkan tes TCSS); variabel perancu adalah demografi, kadar hemoglobin A1c (HbA1c) dan durasi menderita DM.

Subjek dilakukan anamnesis, pemeriksaan fisik, dan skrining ND menggunakan TCSS. Penilaian skoring adalah 0-4 (tidak neuropati), 5-6 (neuropati ringan), 7-10 (neuropati sedang), dan 1119 (neuropati berat). Usia dibagi menjadi kelompok dewasa (26-60 tahun) dan lansia (>60 tahun). Lama menderita DM dikelompokkan menjadi $\leq 10$ tahun dan $>10$ tahun.

Dilakukan pemeriksaan kadar serum zink, $\mathrm{HbA1c}$, dan trigliserida. Nilai HbA1c dikatakan normal jika $\leq 6,5 \%$ dan tinggi jika $>6,5 \%$. Trigliserida digolongkan menjadi normal $(<150 \mathrm{mg} / \mathrm{dL})$ dan tinggi $(>150 \mathrm{mg} / \mathrm{dL})$. Kadar zink normal adalah $70-150 \mu \mathrm{g} /$ $\mathrm{dL}$ dan rendah jika $<70 \mu \mathrm{g} / \mathrm{dL}$.

Penelitian ini sudah mendapatkan persetujuan dari Komisi Etik Penelitian RS Dr. Kariadi dengan nomor 335/EC/FK-RSDK/VI/2017. Untuk mengetahui hubungan kadar zink serum serta variabel perancu dengan derajat ND dilakukan uji bivariat kategorikal dengan Mann-Whitney. Variabel diuji komparasi antara subjek di Semarang dan Pemalang. Hasil dikatakan bermakna bila $\mathrm{p}<0,05$. Analisis multivariat menggunakan uji regresi linear.

\section{HASIL}

Penelitian ini dilakukan terhadap 60 subjek yang mayoritas perempuan $(63,3 \%)$, rerata usia $52,4 \pm 4$ tahun, rerata durasi menderita DM 9,4 $\pm 3,4$ tahun. Rerata kadar trigliserida, HbA1c dan serum zink dapat dilihat pada Tabel 1. Terdapat 90\% subjek yang terdiagnosis ND berdasarkan TCSS. Tidak terdapat perbedaan karakteristik subjek yang berdomisili di Semarang maupun Pemalang (Tabel 2).
Jika dikelompokkan berdasarkan derajat ND, terdapat 6 subjek tidak mengalami ND, 3 subjek mengalami ND derajat ringan, 19 subjek mengalami ND derajat sedang dan 32 subjek mengalami ND berat. Usia, durasi DM, kadar trigliserida, HbAlc cenderung meningkat sesuai derajat keparahan ND. Rerata kadar zink serum terlihat cenderung menurun secara signifikan seiring makin beratnya ND $(p<0,05)$.

Setelah melalui beberapa tahap pengujian multivariat antar variabel dengan masing-masing derajat ND (Tabel 4) didapatkan kadar trigliserida dan durasi menderita DM memiliki hubungan signifikan dalam memengaruhi derajat ND.

\section{PEMBAHASAN}

Penelitian ini dilakukan terhadap 60 subjek dengan ND yang mayoritas perempuan $(63,3 \%)$, sesuai dengan populasi penelitian Hutapea dkk di RSUP Prof Dr. R. D. Kandou Manado yaitu 54\%. ${ }^{10}$ Rerata usia penelitian ini adalah usia yang relatif sesuai dengan penelitian Bansal (57,1 $\pm 9,7$ tahun) dan Guangyu (54,67 $\pm 10,9$ tahun). ${ }^{9,11}$ Rerata durasi menderita DM pada subjek penelitian ini sesuai dengan Lee dkk bahwa durasi menderita DM pada subjek DM dengan ND adalah 9,64 $\pm 6,77$ tahun, sedangkan pada subjek dengan DM saja 12,00 $\pm 8,68$ tahun. ${ }^{12}$

Rerata kadar trigliserida dan $\mathrm{HbA1c}$ penelitian ini lebih tinggi dari normal. Hal ini sesuai dengan Lee dkk yang mendapatkan kadar trigliserida 171,07 $\pm 148,87 \mathrm{mg} / \mathrm{dL}$ dan $\mathrm{HbAlc} 8,14 \pm 1,63 \%$. Adapun rerata kadar serum zink penelitian ini normal, berbeda dengan Jyothirmayi dkk yang mendapatkan penurunan kadar zink menjadi $50 \pm 12,5 \mu \mathrm{g} / \mathrm{dL}$ pada subjek DM dengan komplikasi. Hampir semua subjek penelitian ini $(90 \%)$ terdiagnosis ND berdasarkan TCSS (Tabel 1), mirip dengan penelitian Karki, didapatkan 100\% subjek dengan ND. ${ }^{12-14}$

Penelitian ini menunjukkan hubungan yang bermakna antara kadar zink serum dengan derajat ND. Dengan melihat rerata kadar zink serum pada masing-masing kelompok derajat ND, didapatkan rerata yang cenderung menurun. Hal ini sesuai dengan Olaniyan dkk, adanya penurunan serum zink 
Tabel 1. Karakteristik Subjek $(n=60)$

\begin{tabular}{|c|c|c|c|}
\hline Variabel & n (\%) & Rerata \pm SD & Median (Min-Maks) \\
\hline \multicolumn{4}{|l|}{ Jenis Kelamin } \\
\hline - Laki-laki & $22(36,7)$ & & \\
\hline - Perempuan & $38(63,3)$ & & \\
\hline $\begin{array}{l}\text { Usia } \\
\text { - Dewasa } \\
\text { - Lansia }\end{array}$ & $\begin{array}{c}59(98,3) \\
1(1,7)\end{array}$ & $52,4 \pm 4$ & $54(44-60)$ \\
\hline \multicolumn{4}{|l|}{ Demografi } \\
\hline - Semarang & $30(50)$ & & \\
\hline - Pemalang & $30(50)$ & & \\
\hline $\begin{array}{l}\text { Lama Menderita DM } \\
\text { - } \leq 10 \text { tahun } \\
\text { - }>10 \text { tahun }\end{array}$ & $\begin{array}{l}27(45) \\
33(55)\end{array}$ & $9,4 \pm 3,4$ & $12(4-14)$ \\
\hline $\begin{array}{l}\text { Kadar Trigliserida } \\
\text { - Normal } \\
\text { - Tinggi }\end{array}$ & $\begin{array}{l}21(35) \\
39(65)\end{array}$ & $172,1 \pm 40,9$ & $171(96-265)$ \\
\hline $\begin{array}{l}\text { Kadar HbA1c } \\
\text { - Normal } \\
\text { - Tinggi }\end{array}$ & $\begin{array}{c}6(10) \\
54(90)\end{array}$ & $9 \pm 2$ & $8,9(4,2-13,1)$ \\
\hline $\begin{array}{l}\text { Kadar Zink } \\
\text { - Normal } \\
\text { - Tinggi }\end{array}$ & $\begin{array}{l}37(61,7) \\
23(38,3)\end{array}$ & $80,6 \pm 24,7$ & $82,7(22,56-132,68)$ \\
\hline Neuropati Diabetik & & $12,1 \pm 5$ & $15(2-19)$ \\
\hline - Tidak neuropati & $6(10)$ & & \\
\hline - Neuropati ringan & $3(5)$ & & \\
\hline - Neuropati sedang & $19(31,7)$ & & \\
\hline - Neuropati berat & $32(53,3)$ & & \\
\hline
\end{tabular}

DM: diabetes melitus; min-maks: minimal-maksimal.

secara signifikan antara penderita DM dibandingkan kontrol. ${ }^{15}$

Zink berperan pada fungsi insulin melalui efek langsung pada sinyal insulin dan efek tidak langsung pada pengaturan faktor pertumbuhan insulin (insulin growth factor). Zink merangsang beberapa komponen, seperti tirosin fosforilasi reseptor insulin b-subunit, phosphoinositide (PI) 3-kinase, fosforilasi tirosin insulin receptor substrate (IRS) -1 , dan fosforilasi serin-473 terkait dengan efek zink pada pensinyalan insulin. Bagian dari kutub kation zink dalam sel $\beta$ bekerja sama dengan sekresi insulin setelah stimulasi dari glukosa. ${ }^{16}$

Liu dkk juga mendapatkan bahwa suplementasi zink pada tikus yang diinduksi DM dapat mencegah penurunan kecepatan konduksi saraf motorik. Suplementasi zink dapat meningkatkan transkripsi messenger RNA (mRNA) dari metalotionein yang merupakan antioksidan untuk mencegah stres oksidatif yang dipicu oleh hiperglikemia. ${ }^{6,15}$

Pada penelitian ini tidak didapatkan hubungan yang signifikan antara usia dengan derajat ND. Hal ini bertentangan dengan Karki dkk yang mendapatkan hubungan signifikan di antara keduanya. Pada penelitian tersebut, selain usia juga diamati faktor durasi menderita DM, dan didapatkan kesetaraan antara usia dan durasi menderita DM. Semakin tua usia semakin lama durasi menderita DM. Sedangkan pada penelitian ini antara usia dan lama menderita DM tidak berbanding lurus. Beberapa pasien menderita DM pada usia tua, sehingga tidak berpengaruh terhadap derajat ND. ${ }^{13}$

Penelitian ini mendapatkan hubungan yang bermakna antara kadar trigliserida serum dengan 
Tabel 2. Karakteristik Data Berdasarkan Demografi Subjek

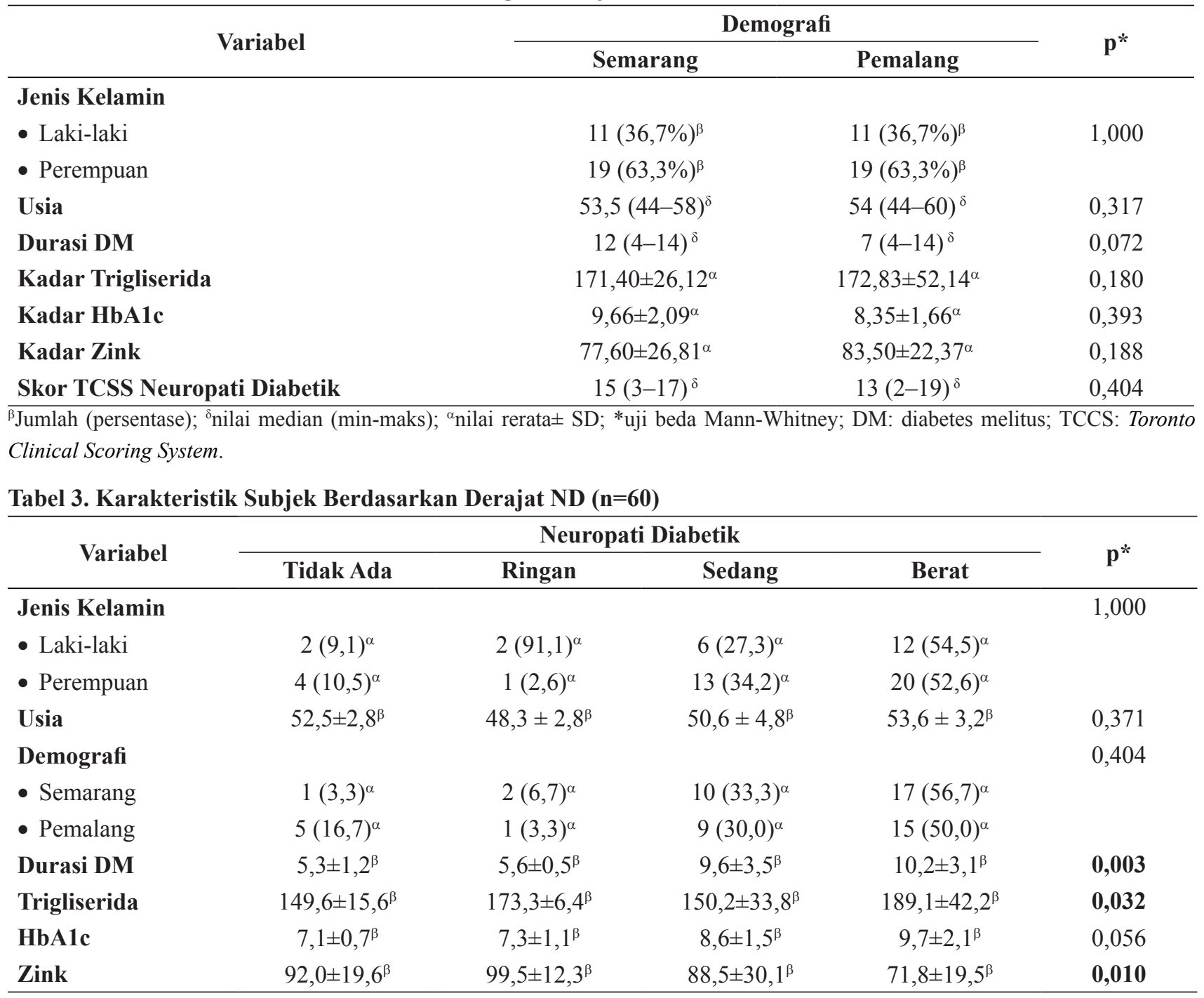

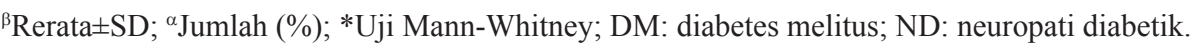

Tabel 4. Uji Multivariat terhadap Derajat Neuropati Diabetik

\begin{tabular}{lc}
\hline \multicolumn{1}{c}{ Variabel } & p \\
\hline Trigliserida & 0,02 \\
Durasi menderita DM & 0,00 \\
\hline
\end{tabular}

DM: diabetes melitus.

derajat ND, sesuai dengan Subbalakshmi yang menyebutkan hipertrigliseridemia berhubungan dengan beratnya neuropati somatik pada DM tipe 2. Kadar trigliserida yang tinggi menjadi faktor prediktif penurunan secara dramatis pada masa jenis atau kepadatan serabut mielin saraf. Kurangnya aksi insulin meningkatkan influks asam lemak ke dalam sel saraf, menyebabkan disfungsi mitokondria, anomali sinyal protein kinase $\mathrm{C}$, dan mengganggu fungsi membran plasma. Low-density lipoprotein (LDL) teroksidasi akan terikat pada reseptor sel dan menimbulkan reaksi stres oksidatif, memperburuk fungsi mitokondria, dan mengubah sifat kelistrikan sel saraf. Studi tersebut membuktikan bahwa terapi antioksidan lipid, mengurangi kolesterol, dan trigliserida berpengaruh terhadap progres keparahan polineuropati diabetik. ${ }^{17-20}$

Penelitian ini mendapatkan hubungan yang bermakna antara kadar HbAlc dengan ND. Hal ini bisa disebabkan oleh tidak diperhatikannya status pengobatan subjek, sehingga bisa menyebabkan bias data. Namun, jika dilihat dari rerata HbAlc pada masing-masing kelompok didapatkan semakin tinggi kadar $\mathrm{HbA1c}$, maka semakin tinggi derajat ND. 
Pada penelitian ini, terdapat hubungan yang bermakna antara durasi menderita DM dengan derajat neuropati. Hal ini sesuai bahwa semakin lama durasi menderita DM, maka semakin tinggi pula derajat komplikasi yang dialami karena kadar glukosa dalam darah akan merusak dinding pembuluh darah kapiler yang berhubungan langsung ke saraf. Akibatnya, saraf tidak dapat mengirimkan pesan secara efektif. Kumar juga menyebutkan bahwa ND berhubungan signifikan dengan kadar $\mathrm{HbA1} \mathrm{c}$ dan durasi diabetes. Studi lain yang meneliti 133 pasien insulindependent diabetes mellitus (IDDM) setelah difollow up selama 10 tahun menunjukkan penurunan kecepatan konduksi saraf pada 6 saraf perifer yang dievaluasi. $^{21-22}$

Hiperglikemia yang berkepanjangan merupakan dasar terjadinya perkembangan ND. Ambilan glukosa pada jaringan saraf perifer terjadi secara insulin independen, sehingga pelepasan atau hasil akhir glukosa dihubungkan dengan jalur poliol yang nantinya akan diubah menjadi sorbitol dan fruktosa oleh enzim aldose reductase dan sorbitol dehidrogenase. Sel membran saraf dikatakan relatif impermeabel terhadap sorbitol dan fruktosa, yang nantinya akan berakumulasi pada jaringan saraf. Fruktosa dan sorbitol secara osmotik aktif menimbulkan peningkatan konsentrasi air pada jaringan saraf. Selanjutnya akan terjadi oksidasi atau reduksi sel dengan penurunan kadar nicotinamideadenin dinucleotide phosphate (NADPH) dan glutation. ${ }^{20-21}$

Proses tersebut akan menimbulkan kaskade, seperti penurunan aktivitas membran Na-K ATPase, akumulasi sodium intraaksonal yang menyebabkan penurunan kecepatan hantar saraf dan perubahan struktural dari jaringan saraf. Kadar mioinositol menurun karena peningkatan dari glukosa dan sorbitol untuk uptake mioinositol pada jaringan dan sel-sel. Penurunan NADPH, yaitu suatu kofaktor untuk enzim nitric oxide synthase, penurunan formasi nitrit oksida menimbulkan vasodilatasi yang menyebabkan kegagalan suplai darah ke jaringan saraf. ${ }^{20-21}$

Analisis multivariat menunjukkan bahwa variabel yang berpengaruh secara bermakna baik secara sendiri ataupun bersama dengan variabel yang lain terhadap derajat ND adalah kadar trigliserida dan durasi menderita DM. Sedangkan untuk variabel zink tidak dominan memengaruhi derajat ND. Zink merupakan faktor pendukung terjadinya ND, sehingga pada penelitian ini didapatkan rerata zink yang masih tergolong normal sedangkan jumlah persentase penderita ND mencapai $90 \%$.

Penelitian ini banyak memiliki keterbatasan antara lain: peneliti tidak melakukan food recall keseharian subjek sehingga tidak diketahui asupan makanan pasien yang dapat memengaruhi kadar zink; pengambilan sampel zink serum terhadap pasien dilakukan seketika tanpa puasa terlebih dahulu sehingga asupan makanan yang dikonsumsi sebelum dilakukan pengambilan sampel dapat memengaruhi hasil pemeriksaan zink; peneliti tidak melakukan pemantauan terhadap obat-obatan yang dikonsumsi subjek termasuk obat penurun kadar gula darah.

\section{KESIMPULAN}

Terdapat hubungan yang signifikan antara kadar serum zink, kadar trigliserida, kadar HbAlc, usia, dan durasi menderita DM dengan derajat ND. Uji multivariat menunjukkan durasi menderita DM dan kadar trigliserida berhubungan dengan ND secara independen.

\section{DAFTAR PUSTAKA}

1. Perkeni. Konsensus pengendalian dan pencegahan diabetes melitus tipe 2 di Indonesia; 2015.

2. World Health Organization. Diabetus mellitus type 2; 2015.

3. Dinas Kesehatan Provinsi Jawa Tengah. Profil kesehatan Provinsi Jawa Tengah tahun 2016; 2016.

4. Papatheodorou K, Banach M, Bekiari E, Rizzo M, Edmonds M. Complications of diabetes 2017. J Diabet Res. 2018;2018:1-4.

5. Luo Y, Zhao J, Han X, Zhou X, Wu J, Ji L. Relationship between serum zinc level and microvascular complications in patients with type 2 diabetes. Chin Med J (Engl). 2015;128(24):3276-82.

6. Liu F, Ma F, Kong G, Wu K, Deng Z, Wang H. Zinc supplementation alleviates diabetic peripheral neuropathy by inhibiting oxidative stress and upregulating metallothionein in peripheral nerves of diabetic rats. Biol Trace Elem Res. 2014;158(2):211-8.

7. Rahmawati A, Hargono A. Faktor dominan neuropati diabetik pada pasien diabetes melitus tipe 2. JBE. 
2018;6(1):60-8.

8. Novriansyah A, Hakim M, Sudoyo AW, Aninditha T, Herqutanto. Uji diagnostik Toronto Clinical Scoring System terhadap diagnosis neuropati perifer terinduksi kemoterapi. Neurona. 2014;31(2):104-10.

9. Bansal D, Gudala K, Muthyala H, Esam HP, Nayakallu R, Bhansali A. Prevalence and risk factors of development of peripheral diabetic neuropathy in type 2 diabetes mellitus in a tertiary care setting. $\mathrm{J}$ Diabetes Investig. 2014;5(6):714-21.

10. Hutapea FS, Kembuan MA, Sampurno JMP. Gambaran klinis neuropati pada pasien diabetes melitus di poliklinik neurologi RSUP Prof. Dr. R.D. Kandou Periode 2014-2015. e-Clinic. 2016;4(1):1-5.

11. Jaiswal M, Divers J, Dabelea D, Isom S, Bell RA, Martin CL, dkk. Prevalence of and risk factors for diabetic peripheral neuropathy in youth with type 1 and type 2 diabetes: SEARCH for diabetes in youth study. Diabetes Care. 2017;2017:1-7.

12. Lee $\mathrm{W}$, Jang $\mathrm{S}$, Lee $\mathrm{S}$, Lee $\mathrm{H}$. Correlation between the severity of diabetic peripheral polyneuropathy and glycosylated hemoglobin levels: a quantitative study. Ann Rehabil Med. 2016;40(2):263-70.

13. Karki D, Nagila A, Dhakal N, Chhetri S. Prevalence of peripheral neuropathy in diabetes mellitus and its association with therapy, ethnicity and duration of diabetes mellitus. Asian J Med Sci. 2019;10(1):72-6.

14. Jyothirmayi B, Vasantha M. Study of zinc and glycated hb levels in diabetic complications. Int Jour
Pharm Clin Res. 2015;7(5):360-3.

15. Olaniyan. Original article serum copper and zinc levels in Nigerian type 2 diabetic patients. AJDM. 2012;20(2):36-8.

16. Flanik J, Thorleifsson G, Beer NL, Jacobs SB, Grarup $\mathrm{N}$, Burtt NP, dkk. Loss-of-function mutations in SLC30A8 protect against type 2 diabetes. Nat Genet. 2014;46(4):357-63.

17. Subbalakshmi NK, Rao SK, Adhikari PM, Pai SR. Influence of dislipidemia on somatic neuropathy in type 2 diabetes. NUJHS. 2013;3(3):25-30.

18. Refa S, Dewi N. Hubungan antara HbAlc dan kadar lipid serum dengan derajat berat retinopati diabetika. Jurnal Kedokteran Brawijaya. 2013;21(3):138-44.

19. Smith AG, Singleton JR. Obesity and hyperlipidemia are risk factors for early diabetic neuropathy. J Diabetes Complications. 2013;27(5):436-42.

20. Mathebulla SD. Polyol pathway: a possible mechanism of diabetes complications in the eye. AVEH. 2015;74(1):5.

21. Kumar S, Aneja GK, Trivedi A, Atam V, Shankhwar SN, Panwar A. Correlation of diabetic nephropathy and $\mathrm{HbA1C}$ in newly diagnosed type 2 diabetic patients of Western UP. IJSRP. 2014;4(12):3-6.

22. Nisar MU, Asad A, Waqas A, Ali N, Nisar A, Qayyum MA, dkk. Association of diabetic neuropathy with duration of type 2 diabetes and glycemic control. Cureus. 2015;7(8):e302. 